\title{
UNIVERSITY INTELLECTUAL PROPERTY COMMERCIALIZATION: A CRITICAL REVIEW OF LITERATURE
}

\author{
Sabri Mohamad Sharif*, Amiruddin Ahamat, Mariam Miri Abdullah, Juhaini Jabar, Muhammed Hariri \\ Bakri \\ Fakulti Pengurusan Teknologi dan Teknousahawanan, Universiti Teknikal Malaysia, Melaka \\ *sabri@utem.edu.my
}

\begin{abstract}
Universities have specialized facilities and experts to support innovation system of a country. Despite the fact that these facilities are being properly utilized at the university level, there are several factors that influence university-led innovation, thus creation of intellectual properties. Some of the highly sought-after innovations are significantly profitable for number of universities. Given that the funding to universities are reducing globally, universities and policymakers would like to utilize these innovations to fund university activities. This study critically reviews the factors that determine the success in university-led IP commercialization to shed light on how the benefit from innovation can be achieved.
\end{abstract}

Keywords: Intellectual Property, Commercialization, University, Innovation

\section{INTRODUCTION}

Commercialization of intellectual properties has significant economic implication for both investors and customers of innovation. On top of the financial rewards for researchers and universities, successful commercialization adds value to social welfare activities, creates long-term research partnership, and generates economic benefit to industries. Intellectual property industry in the United States contributed close to $40 \%$ of the total economic growth (Siwek, 2005). In 2003, the intellectual property industry contributed about $20 \%$ of the private industry's total contribution to the Gross Domestic Product (GDP) of the United States. In monetary terms, the value added by these innovations was US\$1.9 trillion (Chong, 2006). Global competition and the sustainable growth of nations urge for just recognition of intellectual properties, which in turn increase the demand for successful commercialization of university-led ideas.

Intellectual property commercialization process is complex and involves multiple stakeholders. Researchers play an important role in identifying the niche area of innovation and in producing the final form of the product for public consumption. The degree of researchers' involvement in intellectual property commercialization process dictates its terms and conditions, controls the financial benefits to stakeholders, and determines the overall success of the commercialization process (Thursby \& Thursby, 2011b). However, intellectual property commercialization process is not simply about applying for a patent (Hamzah, 2006). Universities provide financial and legal support to researchers while researchers create new technologies to be commercialized. The involvement of many parties, such as the university, government, and industries in the commercialization process, makes commercialization a complex process. Moreover, most researchers lack legal and technical knowledge regarding procedure to commercialize innovations and to ensure financial benefits and private rights. Hence, individual and organizational values and capabilities are important factors in commercialization of intellectual property.

This paper critically reviews existing studies on commercialization process of intellectual property in universities, the factors influencing the process, and the scope and role of values and competencies in achieving the commercialization process.

\section{COMMERCIALIZATION OF INTELLECTUAL PROPERTY}


Innovation is expensive. Historically, corporations establish their own Research and Development (R\&D) department to manage their innovation process more efficiently. However, to meet the increasing social demand for new products at lower cost, industry leaders and governments are turning to universities as a source of innovation. Hence, universities learn about commercialization of intellectual property primarily from industries. The increasing competition for innovation creation and management, resulted in universities are now facing numerous challenges in developing, commercialising, and managing their intellectual properties (Feldman et al., 2002; Donald et al., 2004; Thursby \& Kemp, 2002; Thursby \& Thursby, 2011c).

\section{Definition of Intellectual Property}

According to Article 2 of the conventions of the World Intellectual Property Organisation (WIPO), the term "Intellectual Property" means "all rights resulting from intellectual activity in the industrial, scientific, literary or artistic fields". The World Intellectual Property Organisation (WIPO) is the United Nations (UN) body that administers treaties and conventions related to various Intellectual Property Rights. Their definition of intellectual property includes: "Literary, artistic and scientific works; performances of performing artists, phonograms and broadcasts; inventions in all fields of human endeavour; scientific discoveries; industrial designs; trademarks, service marks, and commercial names and designations; protection against unfair competition and all other rights resulting from intellectual activity in the industrial, scientific, literary or artistic fields" (WIPO, 1967). The above definition indicates the presence of several individual (human endeavour) and organisational (industrial design and protection) characteristics that influence the success or failure of intellectual property commercialization process.

\section{Definition of Intellectual Property Commercialization}

Land, labour, and capital are the three traditional factors of production; the most recent factor is intellectual capital (Madieha, 2004b). The basic tenet behind innovation is that people would like to exploit ownership of properties and use it to contribute toward social development. Hence, ideas become intellectual capital if there exist "originality" and "productivity" in the property (Madieha, 2003; 2004a). Commercialization is closer to "productivity" than originality. Table 1 shows a number of definitions, from dictionary meaning to law firm on theme of work of intellectual property commercialization.

Table 1. Definition of intellectual property commercialization

\begin{tabular}{|c|l|}
\hline References & \multicolumn{1}{c|}{ Definition } \\
\hline Dilanchian (2012) & $\begin{array}{l}\text { Commercialization is a process that adds market value to intellectual } \\
\text { assets. It connects innovation with entrepreneurship. }\end{array}$ \\
\hline $\begin{array}{c}\text { Lexic-Dictionary } \\
\text { (2012) }\end{array}$ & $\begin{array}{l}\text { The act of commercialising involves something in commerce. Both } \\
\text { innovators and acquirer (company/industry/government) will retain } \\
\text { partial ownership of the product/idea. }\end{array}$ \\
\hline WIPO (2006) & $\begin{array}{l}\text { Commercialization is an integrated process starting from scientific } \\
\text { discovery, through development or testing of the basic discovery into } \\
\text { applied research, up to making the ideas commercially viable for social } \\
\text { use. }\end{array}$ \\
\hline Siegel et al. (2004) & $\begin{array}{l}\text { Commercialization starts with university researchers with productive } \\
\text { ideas and ends with a shared ownership control between researchers } \\
\text { and other stakeholders. }\end{array}$ \\
\hline
\end{tabular}

Curtin University, Australia considers intellectual property commercialization as a partnership between innovators and investors (Curtin, 2012). A few lines from the university website provide clear idea about intellectual property and its commercialization: "If you have developed something new and useful that is marketable, we can help you, both financially and logistically, to turn your idea (or 'intellectual property') into a product or service that the wider community can purchase. The process is called 'intellectual property commercialization' and when done right, everybody wins: the inventor 
(you) and the investor (Curtin) benefit financially, gaining funding for further research and the community benefits from the product or service being sold. Typical examples of intellectual property include inventions, computer programs, literary/artistic works and trademarks."

The above quotation elucidates the role of universities and researchers in commercialization. One important message is missing though. How do researchers own technologies unless it is commercialised? Commercialization begins with researcher's idea and, if successfully commercialised, ends in a socially desirable product that is shared by various stakeholders (Siegel et al., 2004).

\section{Benefits of Commercialization}

Countless effort is made globally to use commercialization for entrepreneurship activity. Growth of entrepreneurship in the small and medium enterprises (SMEs) depends largely on the development of low-cost commercialization of university-led ideas (Hammerstedt \& Blach, 2008; Parnami \& Bandyopadhyay, 2008; Rasmussen, 2008; Rasmussen \& Borch, 2010; Rasmussen et al., 2006). WIPO presents a list of benefits of commercialization to all stakeholders. Growth of industrialisation through innovativeness, which increases investment opportunities, is the primary benefit of commercialization. Moreover, more supply-driven innovation helps to enhance technical capabilities of researchers as well as other parties (WIPO, 2006). Supply-driven innovation system refers to a system where universities actively look for innovative sectors and ideas and contribute to those ideas.

Benefits of commercialization are multi-dimensional. Intellectual property commercialization benefits researchers, industries, customers, universities, and government. There are explicit benefits to researchers in terms of financial rewards and professional distinction in scientific community (Siegel $\&$ Phan, 2005). Many researchers have also set up spin-off companies (McQueen \& Wallmark, 1984). Universities, government, and industries have also make sure that innovation rights is transferred according to the legal framework suggested by various global standards (Hughes, 1988). In return, industries and governments get products at a low cost. Companies can capitalise on low-cost strategies while competing in global market. Selling and reselling of the rights purchased by industries from actual innovators can be further utilised as a means of financial gains. Many companies sub-contract their ideas to distributors in exchange for fees or royalties. Hence, property rights bring benefit as long as there is a legal contract and ideas can be exploited (Waldron, 1988).

Table 2. Key stakeholders in university commercialization (Siegel et al., 2004)

\begin{tabular}{|c|c|c|c|c|}
\hline Stakeholder & Actions & $\begin{array}{c}\text { Primary } \\
\text { Motive(s) }\end{array}$ & $\begin{array}{c}\text { Secondary } \\
\text { Motive(s) }\end{array}$ & $\begin{array}{c}\text { Organisational } \\
\text { Culture }\end{array}$ \\
\hline $\begin{array}{c}\text { University } \\
\text { scientist }\end{array}$ & $\begin{array}{c}\text { Discovery of } \\
\text { new knowledge }\end{array}$ & $\begin{array}{c}\text { Recognition in } \\
\text { scientific } \\
\text { community_- } \\
\text { publications, } \\
\text { grants (especially } \\
\text { if untenured) }\end{array}$ & $\begin{array}{c}\text { Financial gain and a } \\
\text { desire to secure } \\
\text { additional research } \\
\text { funding (mainly for } \\
\text { graduate students } \\
\text { and lab equipment) }\end{array}$ & Scientific \\
\hline $\begin{array}{c}\text { Technology } \\
\text { transfer } \\
\text { office }\end{array}$ & $\begin{array}{c}\text { Works with } \\
\text { faculty members } \\
\text { and firms/ } \\
\text { entrepreneurs to } \\
\text { structure deals }\end{array}$ & $\begin{array}{c}\text { Protect and } \\
\text { market } \\
\text { university's } \\
\text { intellectual } \\
\text { property }\end{array}$ & $\begin{array}{c}\text { Facilitate } \\
\text { technological } \\
\text { diffusion and secure } \\
\text { additional research } \\
\text { funding }\end{array}$ & Bureaucratic \\
\hline $\begin{array}{c}\text { Firm/ } \\
\text { entrepreneur }\end{array}$ & $\begin{array}{c}\text { Commercializes } \\
\text { new technology }\end{array}$ & Financial gain & $\begin{array}{c}\text { Maintain control of } \\
\text { proprietary } \\
\text { technologies }\end{array}$ & Organic/ \\
entrepreneurial \\
\hline
\end{tabular}

Siegel et al. (2004) identified three major stakeholders involved in the process of commercialization. Table 2 shows that researchers are important stakeholders in commercialization process. One of the 
goals of the researchers in commercialization is to gain reputation among scientific community, while their secondary motive is to gain financial benefits. These two motives have raised questions as to whether there is a new group of researchers who sacrifice the philosophy of basic research and concentrate only on applied research. There are evidences that higher dependency on applied research, driven by monetary goals, may force researchers to forgo the need to do basic research (Thursby \& Thursby, 2011b). Technology transfer officers are actively involved in providing support to researchers, who often have limited technical and legal knowledge about commercialization. Universities also use technology transfer offices to seek for funds from industries and governments for future research. The new technology derived from commercialization efforts helps reduce the cost of end products, which benefits customers. In turn, customer's satisfaction and growth of industries which are driven by commercialization efforts, benefit governments (Rasmussen, 2008).

\section{INTELLECTUAL PROPERTY COMMERCIALIZATION PROCESS}

Intellectual property commercialization process is complex and can be lengthy. There are various dimensions within the process. The first stage of innovation is researcher's initiative and the final stage is either the creation of a company or rejection of the final product. Hence, it is necessary to understand commercialization process to be able to predict the result of potential commercialization. In other words, success or failure depends largely on the commercialization process itself. To support this view, a number of studies have explained the various dimensions involved in commercialization process. These studies listed the stages of commercialization process in corporate and university intellectual property settings.

\section{Commercialization Process in Corporations}

There is a consensus about the three stages of commercialization of intellectual property: idea generation, development of product and services, and making the product accessible to the general public (Jaiya, 2008; Jelinek, 2006; Jensen \& Thursby, 2001; Shane, 2004; Siegel \& Phan, 2005; Siegel et al., 2004). Marketing activities are aligned with commercialization activities in intellectual property (Pearson \& Miller, 1990). In conventional commercialization process, market activities start after the negotiation is signed with the industry representative by the technology transfer officers. In a modern system, marketing activities are integrated in the commercialization effort. For instance, the five marketing activities highlighted by Pearson and Miller include identifying market demand, conducting active marketing, establishing commercialization rights, creating joint ventures or partnerships (contract management), and forming strategic alliance. Jaiya extended the existing three-stage framework into five stages, which include creation, protection, management formation, exploitation, and due diligence or audit evaluation. However, Jaiya focused mostly on corporate intellectual property management (Jaiya, 2008). Hence, the framework is not suitable for university intellectual property commercialization process. The five-stage model explained by Jaiya is shown in Figure 1.

$\begin{array}{cccc}\text { Invention } & \text { Management } & \text { Due } \\ \text { Protection } & & \text { Exploitation }\end{array}$

Figure 1. Steps in intellectual property commercialization (Jaiya, 2008)

Jaiya elucidated three major dimensions in the commercialization of intellectual property that are significantly different from Pearson and Miller (Jaiya, 2008; Pearson \& Miller, 1990). The three dimensions are discussed in detail below.

i) Protection of Value of Intellectual Property

Protection is geared towards the protection of the created intellectual property (Jaiya, 2008). Protection is vital to prevent the loss of the intellectual property or its value. Loss of an intellectual property or loss of its value is usually in the form of dilution of intellectual property due to infringement on the property. Therefore, an intellectual property, especially the ones which have been identified as having value and having real opportunity of being exploited by the owner, must be protected. Ideally, intellectual property should be protected from the moment it is created 
(Hamzah, 2006). Another issue is exploitation of intellectual property, which refers to the utilization of intellectual property in such manner that brings revenue to an enterprise. There are various methods of exploitation such as licensing, assignment, capitalization, collateralization, and securitization. Although the choice inventors have in the exploitation of their research enables them to maximize their financial gain, if intellectual property is not protected, inventors, in this case university researchers, will be reluctant to innovate (Myers, 2010).

ii) Stages of Intellectual Property Commercialization Process

Management of intellectual property involves several steps, such as identifying intellectual property, recording the property, and designing and implementing database to manage all available intellectual properties (Whittaker, 2003). It is important to understand the degree of involvement of researcher and technology transfer officers in each of these steps.

iii) Monitoring and Evaluation

Another important issue is due diligence or audit evaluation. It is important to determine the size and strength of patent assets held by a company by conducting intellectual property due diligence or audit. The company gathers, organises, and analyses all its intellectual assets, such as products, services, technologies, processes, and business practices.

\section{Commercialization Process at Universities}

Due to the structural differences between corporations and universities, the process for commercialization of the intellectual property between the two is also different. One of the major reasons why universities look at commercialization of intellectual property differently than corporations is because of their social roles (Braunerhjelm, 2007). Figure 2 shows a rough process flow of intellectual property commercialization in universities. The process flow especially shows the importance of socio-economic role that universities play during the commercialization process. The process flow also highlights the role played by different stakeholders, i.e. industry, researchers, and government, during the commercialization process.

Table 3. Stage in commercialization process (WIPO, 2006)

\begin{tabular}{|c|c|c|c|c|c|c|}
\hline $\begin{array}{c}\text { (1) } \\
6 \\
\text { stages }\end{array}$ & Investigation & Feasibility & Assessment & Pilot plant & Growth & Maturity \\
\hline $\begin{array}{c}3 \\
\text { phases }\end{array}$ & Concept & \multicolumn{3}{|c|}{ Development } & \multicolumn{2}{|c|}{ Merger } \\
\hline
\end{tabular}

Universities are emerging as one of the major innovation centers. WIPO stated that there are three major phases in any intellectual property within an institutional setting (WIPO, 2006). The three phases are grouped based on six stages. Table 3 shows that these three phases can be easily explained based on university setting. University researchers engaged heavily in concept initiation and development of prototypes. However, researchers usually lack technical knowledge to take commercial advantage of the prototypes. An important body of literatures on IP commercialization explains how universities are involved in innovation process, and how these innovations can be meaningfully transferred into entrepreneurship and other value-added activities (Braunerhjelm, 2007). To ease the transformation from development to commercialization, universities have set up technology transfer office or technology licensing office (Debackere \& Veugelers, 2005; Kneller, 1999; Marshall, 2002).

Another major limitation of the WIPO framework is that it does not clearly explain the role of major stakeholders, including government and industries. Government is still one of the major sponsors of research in universities. After the research is commercialized, the product is marketed by spin-off companies or licensed to industries. It is vital to take into consideration that some governments have also taken the necessary initiatives to foster university-led research (Rasmussen, 2008). These government initiatives include allocating more resources for the training and development of university faculty members, creating better market for research, and setting up better incentive standard. These initiatives will result in motivated and capable researchers contributing to the process 
of commercializing intellectual property within the university setting. To illustrate these issues, Siegel et al. conducted a qualitative study and explained the process of commercialization of the intellectual property at universities (Siegel et al., 2004). Table 4 lists the stages in university intellectual property commercialization process.

Table 4. Steps in the commercialization of university intellectual property (Siegel et al., 2004)

\begin{tabular}{|c|l|}
\hline Step & \multicolumn{1}{|c|}{ Activity } \\
\hline 1 & Individual researcher generates research idea \\
\hline 2 & Researcher applies for research grant \\
\hline 3 & Application for grant approved or rejected by University Research Office \\
\hline 4 & Researcher carry out research according to schedule \\
\hline 5 & Ultimate Scientific Discovery by University Scientist \\
\hline 6 & Invention Disclosure by University Scientist and Technology Transfer Officers (TTO) \\
\hline 7 & $\begin{array}{l}\text { Evaluation of invention for patenting by University Scientist and Technology Transfer } \\
\text { Officers (TTO) }\end{array}$ \\
\hline 8 & $\begin{array}{l}\text { Application for Patent by University Scientist (or University) and Technology } \\
\text { Transfer Officers (TTO) }\end{array}$ \\
\hline 9 & $\begin{array}{l}\text { Marketing of Technology to firms by University Scientist and Technology Transfer } \\
\text { Officers (TTO) and firms/entrepreneurs }\end{array}$ \\
\hline 10 & $\begin{array}{l}\text { Negotiation of Licenses by University Scientist and Technology Transfer Officers } \\
\text { (TTO) and firms/entrepreneurs }\end{array}$ \\
\hline 11 & $\begin{array}{l}\text { University Scientist and Technology Transfer Officers (TTO) and firms/entrepreneurs } \\
\text { award license to firms (existing or start-up) }\end{array}$ \\
\hline
\end{tabular}

As shown in Table 4, commercialization of university intellectual property starts with faculty members; intention to innovate new ideas. Faculty members make application for research funding from various universities, private, and government sources. At present, universities especially in Malaysia assist faculty members to obtain funds for their research through a separate innovation management office commonly referred to as centre for research and innovation management. During the innovation process, the centre for research and innovation management takes care of the due diligence of faculty members. The centre monitors academic and innovation behavior of researchers and their timeline with research proposal, and evaluates the quality of research based on preestablished standards. When the innovation is complete, a prototype of the idea is transferred to technology transfer office. This office is responsible for facilitating transformation of ideas into commercial sable products. The office prepares legal documents to manage the transformation using suitable exploitation method such as the licensing or assignment.

Mirowski and Van Horn (2005) support a more generic process in the commercialization of intellectual property. They argue that researchers disclose their innovation, enter into contract with interested industries, and receive financial benefits, if successful. Involvement of researchers decreases with the signing of the contract and transfer of financial benefits. Technology Transfer Officers handle the contract and payment stages on behalf of researchers. Technology transfer officers are officers working for the university and the researchers. Industries are also involved in the contract and payment management functions. The quality of innovation depends largely on the competency of researcher, while disclosure is highly influenced by the intention of researchers. Contract management involves the competencies and attitudes of the technology transfer officers, while payment is influenced by market demand (industry demand) and effective management by technology transfer officers. Thus, both individual and organizational characteristics influence the commercialization process. Overall, 
Figure 2 summarizes the stages involved in commercialization of university intellectual property.

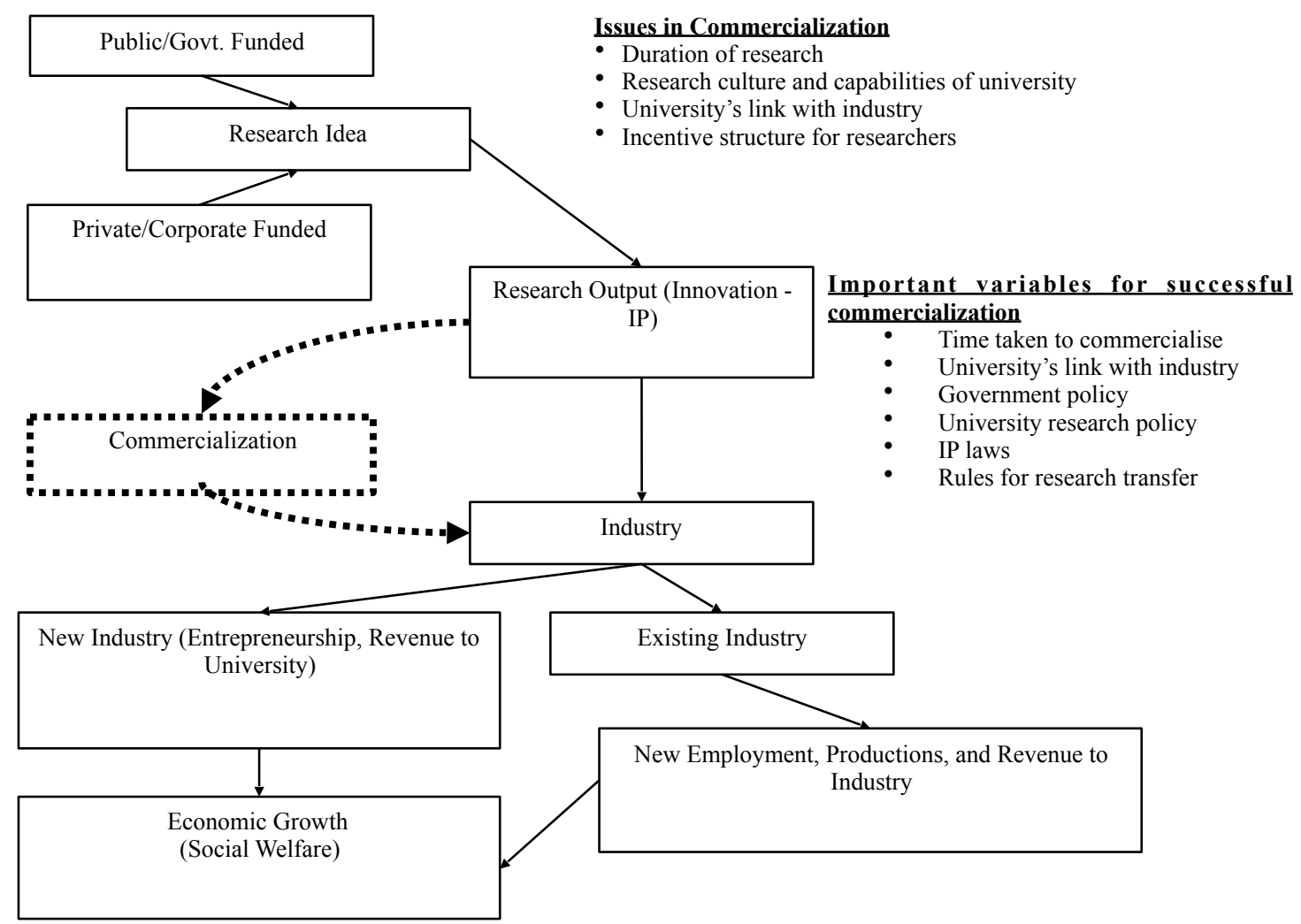

Figure 2. Stages in commercialization and value addition

\section{FACTORS INFLUENCING COMMERCIALIZATION PROCESS}

The process of commercialising intellectual property is time-consuming. A number of factors and stakeholders influences the process. Legal challenges to protect property rights are the primitive layer of factors that exert greater pressure on governments, industries, and innovators (Landes \& Posner, 1989). The second layer of factors which have significant influence on intellectual property commercialization is related to financial matters (Pearson \& Miller, 1990). More recent factors influencing commercialization process is related to entrepreneurship management and relationship management (Autio \& Kauranen, 1994; Haeussler \& Colyvas, 2011). Commercialization is a process through which academic innovations are transferred to industries under legal contracts. As long as the innovations are disclosed, technology transfer office initiates legal formalities to preserve the legal rights of innovation which are commonly referred to as "patenting" in technical term.

\section{Legal Atmosphere}

Patent, copyright, and trademarks not only provide legal protection to innovators, but also unlock the opportunities for cross-border licensing and spin-offs. Hence, legal assistance is a major facilitator in expanding commercialization of intellectual property. In the absence of legal rights, the commercialization process is not secure and researchers would be less interested to commercialize their invention (Ferington, 2007). Economic gains from innovation depend on the establishment of rights on the property. There are three theoretical dimensions in the philosophy behind rights: held in common provision, social welfare, and theory of private rights. Locke (1970) and Nozick (1974) defined the famous "held in common" proviso. Rights of innovation naturally belong to innovators as they had put in their labors to transform natural properties into private properties. In this dimension, innovation management is mostly inventor centric and researchers enjoy most of the benefits from the innovations.

The second and third dimensions emerge at the same time. Developed from the basic philosophies of Kant and Hegel, Hughes (1988) explained "social and private rights", which are considered as the 
source of today's intellectual property rights. Social and private rights differentiate the legal frame works which explain social rights and inventors' rights in innovation. Prior to the social and private rights dimension, there exists another dimension. Landes and Posner $(1987 ; 1989)$ explained the social welfare theory. In this theory, innovation is targeted towards maximising net social value. Hence, most university research fall in this dimension. Theory of Private Rights state the rights of owning the invention by the inventors. When the private right is ensured, inventors can claim ownership and financial benefits on the commercialised innovations. Hughes (1988) is credited for combining both social and legal rights of innovation. In the social and private rights dimension, there is room for contractual relationship between researchers and industries. It encourages innovators to commercialise their ideas, thus increasing the number of innovation. Higher motivation for innovation would positively influence the number of innovation being disclosed. Social and private rights ensure strength of contractual bondage and ensure the financial reward of each stakeholder. Unless these two ideas, the social and the private rights, are combined, the explanation to why innovators should innovate for social benefits will not be justified. Innovators should get due rewards, either through ownership of the idea or financial benefits, for their contribution to society.

Government plays a pivotal role in strengthening the legal atmosphere of intellectual property commercialization. Government facilitates the transfer of innovation in a legally structured manner to industries for public use. Government is like a market maker for intellectual properties (Rasmussen, 2008). Hamzah (2006) argued that $80 \%$ of research funding in Malaysia come from public sources. The Ministry of Science, Technology and Innovation, MOSTI (2009) issued guidelines to be followed by Malaysian universities and industries during the transfer of intellectual property rights. Hence, effective government support can advocate commercialization of university intellectual property. However, the other side of the coin is alarming. Standardised organisation commitment to regulations may impede the growth of intellectual property commercialization (Argyres \& Liebeskind, 1998). There are also claims that governments prefer universities to commercialise more researches that were funded by public sources (Braunerhjelm, 2007).

Government's preference to use public funds for research has, however, been shifting from scientificgovernment to scientific-economic concern (Chang et al., 2005). Therefore, universities are now seeking more private funding. Consequently, decentralised scientific endeavour is accelerated and there would be more opportunities for researchers to seize in commercialization. These philosophies and the shift in legal atmosphere mean that individual and organisational capabilities and values play vital role in the commercialization process. Besides, researchers are now offered equity participation when new companies are formed during the commercialization process (Feldman et al., 2002). Universities, in collaboration with industries and governments, have set up technology transfer offices to facilitate commercialization of intellectual property (Marshall, 2002).

The preceding discussion clearly shows that government's role in intellectual property commercialization depends on other factors. This role is usually positive and more dominant. There are two major issues worth discussing in this regard. Government is the key stakeholder in strengthening the relationship between university and industry (Hearn et al., 2004). Government helps in forming an institutional framework, establishing research culture, and creating markets for innovation in the long-run (Liyanage \& Gluckman, 2004). Therefore, government's role in the commercialization of intellectual property is through the establishment of effective legal framework for innovative research culture, research collaboration, and property rights of researchers. Governments that have succeeded in meeting these challenging tasks see a momentum in the commercialization of intellectual property (Rasmussen, 2008). Finally, government assistance must not be static or standardised. Assistance from the policy level should be highly customised to the needs of commercialization and it must also be dynamic (Braunerhjelm, 2007; Geuna \& Muscio, 2009).

\section{Economic Payoff}

Economic reason is the second most important factor influencing today's growth in commercialization of intellectual property. All three major parties, i.e. researchers, technology transfer officers, and managers in industries, have various economic motives in the commercialization of intellectual property. In the social and private rights dimension, researchers are entitled to ownership of the 
innovation and property thereafter. Historically, researchers have been more interested in ownership of assets (Madieha, 2004a) and their primary goal has been to earn reputation in scientific community (Siegel et al., 2004). However, the recent increase in demand for innovation and competition to produce good quality innovation have raised the bar. It is now evident that researchers do not disclose research without the assurance of sufficient financial rewards (Geuna \& Muscio, 2009; Klein et al., 2009; Thursby et al., 2007).

To put it simply, researchers engage in commercialization of the intellectual property in three ways: a) licensing, b) spin-off entrepreneurship, and c) consultancy work (Benkler, 2002). It is difficult to process the patent of innovation if these financial conditions are not met (Bein et al., 2007). However, if it was not possible to find a way to balance the financial rewards of researchers with other stakeholders, then commercialization would have less impact at the aggregate level (Benkler, 2002). To bring dynamism into financial transaction from commercialization, universities have introduced various entrepreneurial schemes. In return for the research facilities provided by the university, researchers would have to share a part of the financial reward with the university. The transfer or sharing of financial rewards between university and researchers are clearly written in the agreement. This approach has gained momentum in the name of "entrepreneurship university model" with much wider application in industries (Benneworth, 2007). Hence, the flow of and control over financial rewards influence the growth of commercialization of intellectual property.

There are, however, direct reasons behind the economic motives of universities. Commercialization has become a major source of income to many universities. To recover the cost of commercialization and researches led by universities, innovations must bring in higher financial payoffs (Braunerhjelm, 2007). This means that collaboration between researchers and universities is very important in resolving the debate over financial gains from commercialization of intellectual property. The type of contract between university and researchers in managing financial resources also determine the financial motives behind commercialization of intellectual property (Chang et al., 2005; Davis, 2008).

Technology transfer officers have to find a win-win solution. To foster commercialization of intellectual property, technology transfer officers have to offer the best price for innovations that meet the demand of researchers and the requirement of industries. However, technology transfer officers offer different prices based on the prospect of innovation and the strength of contract (Kneller, 1999). On the other hand, technology transfer officers are seen as "hopes" to negotiate with industries on behalf of researchers. Several countries are now setting up technology transfer offices at universities (Marshall, 2002). Putting technology transfer officers in the payroll of universities limits their opportunities to earn commission and management fees. Thus, several individual and organisational values, especially with regard to ethical and moral issues, begin to emerge. Moreover, technology transfer officer's influence does not depend on innovation management philosophies, e.g. top-bottom or bottom-top (Goldfarb \& Henrekson, 2003). As technology transfer officers play a negotiating role, their positive character will provide room for academic freedom, and hence attract more commercialization.

There are two dimensions of economic payoff in industries. These dimensions are direct economic gain from owning a share in innovation, and indirect economic rewards in the reduction of cost from the use of new technology. Studies on university intellectual property commercialization give less emphasis on the economic benefits gained by industries. However, studies suggest that long-term economic progress in industries requires a strong collaboration with universities and government (Leydesdorff, 1996). For instance, Chalmers University of Technology in Sweden has invented more than 400 patents between 1943 and 1994, and 50\% of the patents were used to establish spin-offs (Wallmark, 1997). This not only benefits the university, but also contributed toward industry growth, competition, and employment. However, it is clear that along with flexible innovation management policies in industry, the growth of university-led commercialization is dependent on the attitude and capability of researchers and technology transfer officers.

\section{Support Services, Culture and Innovative Environment}


A group of researchers have highlighted the importance of support services to promote quality research. Universities with capable researchers, cutting-edge research equipment, and good support staff tend to commercialise more. These factors motivate researchers positively and encourage them to commercialise their findings (Autio \& Kauranen, 1994). Growth of commercialization is found to be faster at universities with active participation of research students and professors (Wallmark, 1997). For example, students own $41 \%$ of the patents registered by Chalmers University in Sweden. National innovative capacity is another determinant in the commercialization of intellectual property. Countries with higher research and development manpower and spending commercialise more technologies (Furman et al., 2002). However, Furman et al. (2002) also argued that national innovative capacity provided more boost to high market share and export of high technology, which depend on the degree of openness and technology specialisation practised by researchers. These findings raised questions regarding the influence of individual values and attitude even at the macro level.

The top most priority for quality support services is also closely associated with technology transfer offices. The Technology Transfer Officers (TTO) form a part of university's research ecosystem. Universities with their own technology transfer offices experience dual layer of values: first, at researchers' level, and second, at technology transfer officers' level. Technology transfer office could also be based outside universities. Technology transfer officers function as dual agent between researchers and markets (Jensen et al., 2003). On average, universities with technology transfer offices commercialise more technologies than those without one (Raine \& Beukman, 2002). Jensen et al. (2003) found that researcher's intention to disclose innovation influence the terms of the contract negotiated by technology transfer officers. As they are experienced, technology transfer officers know the expectations and attitude of the researchers and the university research administrators, and prepare the innovation transfer contracts based on the expectations and attitude. Hence, values have profound influence on the commercialization of intellectual property.

University research culture and research specialization are important factors determining the growth of commercialization. Universities with creative disciplines, such as entertainment or media industries, face more challenges if support facilities were less developed. Hearn et al. (2004) argued that in order to ensure more commercialization, universities need to extend their support facilities to form spin-off companies and to set up venture capital firms. Appropriate incentive structure, spin-off support, research decentralization, and monitoring of intellectual property commercialization have profound influence on the commercialization process (Debackere \& Veugelers, 2005). Involvement, level of commitment, and job responsibility of technology transfer officers have positive influence on research environment. In Australian universities, commitment of technology transfer officers have strong influence on the growth of commercialization (Harman \& Stone, 2006). This is yet another example of how both individual and institutional values and competencies influence the growth of commercialization. However, existing intellectual property literature largely ignores the strong influence of values and competencies on commercialization process.

\section{CONCLUSION}

This study reviews existing literature on university intellectual properly commercialization process. Universities are emerging as one of the major innovation centers in developing economies due to various dimensions. These dimensions include shortage of skilled labour in industry (Kroll \& Liefner, 2008), increased research capabilities of and funding for universities (Rasmussen \& Borch, 2010), better collaboration of researchers with industries (Walter et al., 2006), and increased overall government assistance to universities for the creation and management of innovation (Rasmussen, 2008; Rasmussen et al., 2006). With the increased competition in the creation and management of innovation, universities are facing increasing challenge in developing, commercializing, and managing their intellectual properties (Feldman et al., 2002; Siegel et al., 2004; Thursby \& Thursby, 2011a; Thursby \& Kemp, 2002). In addition to their social role as innovators, universities have to efficiently manage a holistic process, from idea generation and fund management to commercializing innovations, while at the same time ensuring that proper rights of innovators are instituted and commercialized products add value to society. Overall, country footprint in innovation can be improved if technology commercialization process at the university level is managed efficiently. This study can be guiding light for universities in developing and emerging countries with limited 
understanding of the power of commercialization.

\section{ACKNOWLEDGEMENTS}

The author would like to thank Universiti Teknikal Malaysia Melaka (UTeM) and Centre for Technopreneurship Development (CTED) for their support in obtaining materials for this study and research.

\section{REFERENCES}

Argyres, N. S., \& Liebeskind, J. P. (1998). Privatizing the intellectual commons: Universities and the commercialization of biotechnology. Journal of Economic Behavior and Organization, 35(4), 427-454. Autio, E., \& Kauranen, I. (1994). Technologist-entrepreneurs versus non-entrepreneurial technologists: Analysis of motivational triggering factors. Entrepreneurship and Regional Development, 6(4), 315-328.

Bein, D., Bein, W., Brut, M. P., \& Cazacu, M. (2007). Why it is hard to patent an innovation? Revista Informatica Economica, 3(43), 18-21.

Benkler, Y. (2002). Intellectual property and the organization of information production. International Review of Law and Economics, 22(1), 81-107.

Benneworth, P. (2007). Seven Samurai opening up the Ivory Tower? The construction of Newcastle as an entrepreneurial university. European Planning Studies, 15(4), 487-509.

Braunerhjelm, P. (2007). Academic entrepreneurship: Social norms, university culture and policies. Science and Public Policy, 34(9), 619-631.

Chang, Y. C., Chen, M. H., Hua, M., \& Yang, P. Y. (2005). Industrializing academic knowledge in Taiwan. Research Technology Management, 48(4), 45-50.

Chong, J. (2006). Strategic management of intellectual property at national level: Developing an integrated IP infrastructure. In Intellectual Property Law and Strategy. Thomson Sweet and Maxwell.

Curtin. (2012). Does your research have commercial potential? investing in innovative research.

Davis, L. (2008). Licensing strategies of the new "intellectual property vendors". California Management Review, 50(2), 6-30.

Debackere, K., \& Veugelers, $R$. (2005). The role of academic technology transfer organizations in improving industry science links. Research Policy, 34(3), 321-342.

Dilanchian, D. (2012). Commercialisation defined. Law library: Commercialisation and knowledge management.

Feldman, M., Feller, I., Bercovitz, J., \& Burton, R. (2002). Equity and the technology transfer strategies of American research universities. Management Science, 48(1), 105-121.

Ferington, D. (2007). Intellectual property protection in a combined academic and private enterprise collaborative environment. In IEEE Portland International Conference on Management of Engineering and Technology, pp. 1975-1981.

Furman, J. L., Porter, M. E., \& Stern, S. (2002). The determinants of national innovative capacity. Research Policy, 31(6), 899-933.

Geuna, A., \& Muscio, A. (2009). The governance of university knowledge transfer: A critical review of the literature. Minerva, 47(1), 93-114.

Goldfarb, B., \& Henrekson, M. (2003). Bottom-up versus top-down policies towards the commercialization of university intellectual property. Research Policy, 32(4), 639-658.

Haeussler, C., \& Colyvas, J. A. (2011). Breaking the Ivory Tower: Academic entrepreneurship in the life sciences in UK and Germany. Research Policy, 40(1), 41-54.

Hammerstedt, R. H., \& Blach, E. L. (2008). Commercialization of basic research from within the university and return of value to the public. Animal Reproduction Science 105, 158-178.

Hamzah, Z. (2006). Intellectual property law and strategy. Sweet and Maxwell Asia.

Harman, G., \& Stone, C. (2006). Australian university technology transfer managers: Backgrounds, work roles, specialist skills and perceptions. Journal of Higher Education Policy and Management, 28(3), 213-230.

Hearn, G., Cunningham, S., \& Ordonez, D. (2004). Commercialisation of knowledge in universities: The case of the creative industries. Prometheus, 22(2), 189-200.

Hughes, J. (1988). The philosophy of intellectual property, Georgetown Law Journal, 77(1988), 1-73.

Jaiya, G. S. (2008). Intellectual property management and commercialization of new products. World 
Intellectual Property Organisation (WIPO).

Jelinek, M. (2006). Industry-university intellectual property dynamics as a multi-level phenomenon. In Research in Multi-Level Issues. Emerald Group Publishing Limited, pp. 259-299.

Jensen, R., \& Thursby, M. (2001). Proofs and prototypes for sale: The tale of university licensing. American Economic Review 91, 240-259.

Jensen, R. A., Thursby, J. G., \& Thursby, M. C. (2003). Disclosure and licensing of university inventions: 'The best we can do with the $s^{* *} t$ we get to work with'. International Journal of Industrial Organization, 21(9), 1271-1300.

Klein, R., de Haan, U., \& Goldberg, A. I. (2009). Overcoming obstacles encountered on the way to commercialize university IP. Journal of Technology Transfer, 35, 671-679.

Kneller, R. (1999). Intellectual property rights and university-industry technology transfer in Japan. Science and Public Policy, 26(2), 113-124.

Kroll, H., \& Liefner, I. (2008). Spin-off enterprises as a means of technology commercialisation in a transforming economy - Evidence from three universities in China. Technovation, 28, 298-313.

Landes, W., \& Posner, R. (1987). Trademark law: An economic perspective. Journal of Law and Economics, 30, 265.

Landes, W., \& Posner, R. (1989). An economic analysis of copyright law. Journal of Legal Studies, 18, 325-363.

Lexic Dictionary. (2012). Definition of commercialisation. http://www.lexic.us/definition-of/ commercialisation.

Leydesdorff, L. (1996). Emergence of a triple helix of university-industry-government relations. Science and Public Policy, 23, 279-286.

Liyanage, S., \& Gluckman, P. (2004). The determinants of biotechnology innovative capability: The dynamics of knowledge and marketplace. International Journal of Biotechnology, 6(2-3), 281-300.

Locke, J. (1970). Two treatises of government. In Second Treatise. Cambridge University Press.

Madieha, I. (2003). Patent law in Malaysia: Cases and commentary. Sweet and Maxwell Asia.

Madieha, I. (2004a). Copyright law in Malaysia: Cases and commentary. Sweet and Maxwell Asia.

Madieha, I. (2004b). Trademarks law in Malaysia: Cases and commentary. Sweet and Maxwell Asia.

Marshall, R. (2002). University technologies: From laboratory to reality. Institution of Chemical Engineers, 732, 22-23.

McQueen, D. H., \& Wallmark, J. T. (1984). Innovation output and academic performance at Chalmers University of Technology. Omega, 12(5), 457-464.

Mirowski, P., \& Van Horn, R. (2005). The contract research organization and the commercialization of scientific research. Social Studies of Science, 35(4), 503-548.

MOSTI. (2009). Intellectual property commercialisation policy for research and development (R\&D) projects funded by the government of Malaysia. Ministry of Science, Technology and Innovation Malaysia.

Myers, G. (2010). Toward a unified theory of intellectual property misuse. http://ssrn.com/ abstract $=1507173$.

Nozick, R. (1974). Anarchy, state and Utopia. Basic Books.

Parnami, N., \& Bandyopadhyay, D. T. K. (2008). Academic research and intellectual property. http:// www.intelproplaw.com/Articles/files/Article.pdf.

Pearson, H., \& Miller, C. (1990). Commercial exploitation of intellectual property. Wiley and Sons.

Raine, J. K., \& Beukman, C. P. (2002). University technology commercialisation offices - A New Zealand perspective. International Journal of Technology Management, 24(5-6), 627-647.

Rasmussen, E. (2008). Government instruments to support the commercialization of university research: Lessons from Canada. Technovation, 28(8), 506-517.

Rasmussen, E., \& Borch, O. J. (2010). University capabilities in facilitating entrepreneurship: A longitudinal study of spin-off ventures at mid-range universities. Research Policy, 39(5), 602-612.

Rasmussen, E., Moen, Ø., \& Gulbrandsen, M. (2006). Initiatives to promote commercialization of university knowledge. Technovation, 26(4), 518-533.

Shane, S. (2004). Academic entrepreneurship - University spinoffs and wealth creation. Edward Elgar. Siegel, D. S., \& Phan, P. H. (2005). Analyzing the effectiveness of university technology transfer: Implications for entrepreneurship education. In Advances in the Study of Entrepreneurship, Innovation, and Economic Growth. Emerald Group Publishing Limited, pp. 1-38.

Siegel, D. S., Waldman, D. A., Atwater, L. E., \& Link, A. N. (2004). Toward a model of the effective 
transfer of scientific knowledge from academicians to practitioners: Qualitative evidence from the commercialization of university technologies. Journal of Engineering and Technology Management, 21, 115-142.

Siwek, S. E. (2005). Engines of growth: Economic contributions of the U.S. intellectual property industries. Social Science Research Council.

Thursby, J., \& Thursby, M. (2011a). Faculty participation in licensing: Implications for research. Research Policy, 40(1), 20-29.

Thursby, J. G., \& Kemp, S. (2002). Growth and productive efficiency of university intellectual property licensing. Research Policy, 31(1), 109-124.

Thursby, J. G., \& Thursby, M. C. (2011b). Faculty participation in licensing: Implications for research. Research Policy, 40(1), 20-29.

Thursby, J. G., \& Thursby, M. C. (2011c). Has the Bayh-Dole act compromised basic research? Research Policy, 40(8), 1077-1083.

Thursby, M., Thursby, J., \& Gupta-Mukherjee, S. (2007). Are there real effects of licensing on academic research? A life cycle view. Journal of Economic Behavior and Organization, 63(4), 577-598.

Waldron, J. (1991). The right to private property. Clarendon Press.

Wallmark, J. T. (1997). Inventions and patents at universities: The case of Chalmers University of Technology. Technovation, 17(3), 127-139.

Walter, A., Auer, M., \& Ritter, T. (2006). The Impact of network capabilities and entrepreneural orientation on university spin-off performance. Journal of Business Venturing, 21, 541-567.

Whittaker, J. B. (2003). Strategy and performance management in the government. http:// www.exinfm.com/workshop_files/strategy_pm_gov.pdf.

WIPO. (1967). World Intellectual Property Organization Convention. In Article 2. WIPO.

WIPO. (2006). Basic issues in technology commercialisation: From concept to market. http:// www.wipo.int/uipc/en/documents/pdf/okongwus_iptto_1.pdf. 